\title{
Conceptual Understanding of Osmosis and Diffusion by Australian First-year Biology Students
}

\author{
Nicole B. Reinke ${ }^{\mathrm{a}}$, Mary Kynn ${ }^{\mathrm{a}}$ and Ann L. Parkinson ${ }^{\mathrm{a}}$ \\ Corresponding author: Nicole B. Reinke (nreinke@ usc.edu.au)

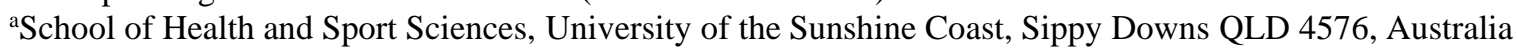

Keywords: biology, osmosis, diffusion, conceptual assessment, misconception

\begin{abstract}
Osmosis and diffusion are essential foundation concepts for first-year biology students as they are a key to understanding much of the biology curriculum. However, mastering these concepts can be challenging due to their interdisciplinary and abstract nature. Even at their simplest level, osmosis and diffusion require the learner to imagine processes they cannot see. In addition, many students begin university with flawed beliefs about these two concepts which will impede learning in related areas. The aim of this study was to explore misconceptions around osmosis and diffusion held by first-year cell biology students at an Australian regional university. The 18item Osmosis and Diffusion Conceptual Assessment was completed by 767 students. From the results, four key misconceptions were identified: approximately half of the participants believed dissolved substances will eventually settle out of a solution; approximately one quarter thought that water will always reach equal levels; one quarter believed that all things expand and contract with temperature; and nearly one third of students believed molecules only move with the addition of external force. Greater attention to identifying and rectifying common misconceptions when teaching first-year students will improve their conceptual understanding of these concepts and benefit their learning in subsequent science subjects.
\end{abstract}

\section{Introduction}

There is a world-wide focus on science, technology, education and mathematics (STEM) education with a drive towards increasing the number of university graduates who are skilled in these areas (Blackley \& Howell, 2015; Chubb, 2012). Many students view science as difficult, boring or presented in an uninteresting way (Chubb, 2011). The proportion of Australian high school students choosing to complete higher level STEM subjects such as chemistry, biology, mathematics and physics has declined (Chubb, 2012; Kennedy, Lyons, \& Quinn, 2014). Despite numerous investigations into the way STEM education is facilitated, the desired increase in student performance and sustained engagement has failed to occur (Johnson, 2012). In 2012 the Australian government increased funding to expand tertiary places for all students who met basic entry requirements for higher education (King \& James, 2013; Marginson, Tytler, Freeman, \& Roberts, 2013). This action resulted in higher numbers of traditionally under-represented students entering the higher education arena (Collier \& Morgan, 2008). There are more students with lower levels of academic preparedness and social and cultural capital, and more students who are first in their family to attend university (Kift, 2015). The change in student demographics, together with the reduced proportion of high school students electing to study biology and chemistry, are likely to be reflected in the university arena. More specifically, there will be a higher proportion of first-year students who have low prior knowledge and ineffective learning strategies in key science disciplines and/or poor student transition into the first year of university (Sturges \& Maurier, 2013; Thalluri, 2016). As studies in first-year biology are required in the majority of science and health programs, 
investigation of biology instruction to students with a wider range of backgrounds should be a key focus for education reform.

Traditionally, students have found learning biology to be challenging mainly due to the vast amount of knowledge available, the complexity of the concepts, and the interdisciplinary nature of the subject (Çimer, 2012). Many of the key biological principles require students to imagine the abstract, i.e. something they cannot see (Ferdig, Blank, Kratcoski, \& Clements, 2015; Tibell \& Rundgren, 2010). Fundamental biological concepts, such as cell membrane structure and function, are key to understanding a large quantity of the first-year biology curriculum. Failure to master these and related concepts is likely to contribute to the attrition of first-year science students. Diffusion and osmosis are key processes that occur in all cells, and form part of a core physiological concept of flow down gradients (Michael, William, McFarland, Modell, \& Wright, 2017). Diffusion is the process whereby solute particles cross the cell membrane and move into or out of cells. It defines the net movement of these molecules, such as nutrients and waste products, from an area of high concentration to an area of low concentration. Osmosis is a similar process, but differs in that it describes the movement of water molecules across the cell membrane (Urry et al., 2018). Understanding these central concepts is vital to mastering a wide range of biological functions (Fisher, Williams, \& Lineback, 2011) including key processes involving plant and animal cells, tissues, organs and organ systems.

Several factors have been investigated in an attempt to determine their importance in supporting student success in first-year biology. Many studies have reported that students with higher university entrance scores and/or prior learning in biology or chemistry perform better on first-year biology assessments (Bone \& Reid, 2011; Burke da Silva \& Hunter, 2009; Graham, Addy, Huddleston, \& Stallard, 2011; Johnson \& Lawson, 1998; McCoy \& Pierce, 2004; Rayner, 2014; Sadler \& Tai, 2007). However, Bone and Reid (2011) also reported that prior learning in biology was only of benefit if students also had prior learning in chemistry. Anderson, Sheldon and Dubay (1990) did not find any association between prior science learning and academic performance in first-year biology; however, their study only examined student learning in photosynthesis and respiration and not overall subject achievement. In contrast, Johnson and Lawson (1998) reported that reasoning ability and not prior biology knowledge was one important factor in determining student success in a first-year biology course.

It is well documented that many students commence biology subjects with pre-existing misconceptions about biological concepts (Anderson et al., 1990; Lazarowitz \& Lieb, 2006; Sanger, Brecheisen, \& Hynek, 2001). These misconceptions, also known as alternate conceptions, or faulty mental models, refer to a student's view of a scientific concept that is different from that generally accepted by scientists (Bekkink, Rogier Donders, Kooloos, de Wall, \& Ruiter, 2016). To facilitate the identification of common misconceptions, teachers and researchers have developed conceptual assessments in the form of diagnostic tests that not only provide a way to measure student learning, but also investigate and diagnose misconceptions held by specific student groups. These assessments have identified common erroneous views and have explored students' mental models of many scientific concepts related to, for example, genetics (Bowling et al., 2008; Smith, Wood, \& Knight, 2008), chemical bonding (Tan \& Treagust, 1999), photosynthesis and respiration (Haslam \& Treagust, 1987). Fisher et al. (2011) developed the Osmosis and Diffusion Conceptual Assessment (ODCA) by modifying an existing conceptual assessment called the Diffusion and Osmosis Diagnostic Test (DODT; Odom, 1995; Odom \& Barrow, 1995). Both of these assessments were developed to assess students' scientific understanding of the events that occur during osmosis and diffusion, as well 
as common misconceptions about these processes (Fisher et al., 2011; Odom, 1995; Odom \& Barrow, 1995).

Identifying and correcting common misconceptions to facilitate further learning is based on a constructivist philosophy (Smith, diSessa, \& Roschelle, 1993). Constructivist theories of learning are grounded on the tenets that learning is an active process of knowledge construction and that knowledge is built on prior understandings (Bada \& Olusegun, 2015). Students approach a learning situation with knowledge they bring from previous experience; this prior knowledge influences their construction of new knowledge, and their new learning experiences also modify their existing knowledge (Phillips, 1995). Therefore, if students have created flawed conceptions prior to new instruction, then this will impede further cognitive development. These faulty mental models will need to be corrected, or rebuilt, before new correct knowledge can be assimilated (Badenhorst, Hartman, \& Mamede, 2016). Correcting misconceptions is important across many disciplines including biology, as concepts from various fields are interrelated and build in complexity and associations.

Cell Biology is a large first-year, single semester course in science and health programs at the University of the Sunshine Coast (USC), a regional university situated in Queensland, Australia. It is a required component of 18 degree programs and can be chosen as an elective component in other programs. Cell Biology explores the cellular basis of life in eukaryotic and prokaryotic organisms, introduces the structure and function of the different types of cells, and introduces scientific methods and skills that are specific to biology. At USC, Cell Biology is delivered in a blended format. The face-to-face components consist of two hours of lectures (including drawing and multimedia activities) per week and a two-hour tutorial/laboratory class in alternate weeks. Complementary learning and assessment resources, such as instructional videos, revision questions, quizzes, vodcasts and assessment submission portholes, are accessed via the learning management system. An analysis of student examination performance in recent years revealed that many did not perform well on examination questions related to the concepts of osmosis, diffusion and concentration gradients. Furthermore, at the end of semester, many still had a poor overall understanding of concepts involving the structure and functions of the cell membrane.

The aim of this study was to gain an understanding of the misconceptions about osmosis and diffusion held by biology students within the context of Australia's changing tertiary education arena. We examined the conceptual understanding of osmosis and diffusion using the ODCA tool (Fisher et al., 2011) on a population of first-year cell biology students at the USC. Two research questions were addressed:

1. What are the common misconceptions about the osmosis and diffusion concepts held by a population of first-year biology students at a regional Australian university?

2. How do these results compare with other published ODCA results?

\section{Methods}

Students enrolled in the first-year course LFS100 Cell Biology during Semester 1 in 2016 and 2017 were invited to participate in this study. The Cell Biology subject services both sciencefocused and non-science-focused programs (Table 1), yet there is no requirement for the completion of high school science subjects to gain entry into these programs. 
This research project was approved by the Human Research Ethics Committee at USC (Approval Number A16806). In week five (2016) or six (2017) of the semester, and after lectures on osmosis and diffusion had been presented, student volunteers were recruited. Of the 965 students enrolled in the course, 767 agreed to participate in the study by completing a modified version of the ODCA (Fisher et al., 2011).

The ODCA consists of two-tiered, multiple choice question pairs (sets). The first tier is the 'what?' component that requires students to think about a specific situation and to either identify a key component/process or to make a prediction. These questions are typically lower level (Shimizu, 2015), requiring a superficial level of understanding. The second tier questions follow from the first tier and require a deeper conceptual understanding. These questions ask why or in what circumstances the prediction will occur (Shimizu, 2015). The incorrect options in the tier two questions represent common misconceptions with regard to the concept (Fisher et al., 2011). This conceptual assessment tool was validated on 408 American university students (Fisher et al., 2011). Two of the original ODCA questions were modified to be relevant to the regional Australian context. This included the removal of references to Imperial units (gallons) and changes to use the Australian English spelling of words such as 'color' to 'colour'. Students were allowed 25 minutes to complete a paper version of the ODCA under examination conditions.

The percentage of students selecting each option for each individual question were calculated and, for each question pair, the percentage of students selecting the correct answer (tier one) for the correct reason (tier two) was also calculated. Demographic data was collated from course enrolment data and Chi-squared tests of association were used to compare cohort characteristics from 2016 and 2017. All analysis was performed in IBM SPSS, version 25.

\section{Results}

Students enrolled in Cell Biology reflected the demographic characteristics of the university in general: approximately two thirds were female and one third were male. Approximately one third of the students were classed as mature age (over 20 years) and there were only a small proportion of international students (less than 5\%). Nearly half of the students were the first in their family to attend university. The programs identified as science-focused accounted for $59 \%$ of the enrolments (Table 1). Overall $80 \%$ of enrolled students participated in the study with no significant difference in participation between science and non-science focused programs.

Table 1. Demographic characteristics of Cell Biology students at USC by year.

\begin{tabular}{|l|c|c|}
\hline & 2016 & 2017 \\
$n(\%)$ & $n(\%)$ \\
\hline Gender & $316(65.3)$ & $303(63.0)$ \\
$\quad$ Female & $168(34.7)$ & $178(37.0)$ \\
$\quad$ Male & $318(65.7)$ & $290(60.3)$ \\
\hline Age Group & $166(34.3)$ & $191(39.7)$ \\
$\quad<=20$ & $460(95.0)$ & $462(96.0)$ \\
$>20$ & $24(5.0)$ & $19(4.0)$ \\
\hline Citizenship & & \\
$\quad$ Domestic & $99(20.5)$ & $121(25.2)$ \\
$\quad$ International & & \\
\hline Program & & \\
Bachelor of Biomedical Science* &
\end{tabular}




\begin{tabular}{|l|c|c|}
\hline Bachelor of Science* & $78(16.1)$ & $52(10.8)$ \\
Bachelor of Animal Ecology & $57(11.8)$ & $83(17.3)$ \\
Bachelor of Nutrition & $56(11.6)$ & $59(12.3)$ \\
Bachelor of Clinical Exercise Science* & $55(11.4)$ & $48(10.0)$ \\
Bachelor of Nutrition \& Dietetics* & $43(8.9)$ & $39(8.1)$ \\
Bachelor of Education (Secondary)/Science & $25(5.2)$ & $12(2.5)$ \\
Associate Degree in Medical Laboratory Science* & $19(3.9)$ & $14(2.9)$ \\
Other & $51(10.6)$ & $53(11.0)$ \\
\hline Enrolment Type & & \\
New & 339 & 338 \\
Continuing & 145 & 143 \\
\hline First in Family & $221(45.7)$ & $232(48.2)$ \\
Yes & $263(54.3)$ & $249(51.8)$ \\
No & 484 & 481 \\
\hline Total Enrolments & $364(75.4)$ & $403(83.8)$ \\
\hline Participants &
\end{tabular}

*identified as science-focused programs

There was no significant difference in the overall ODCA results/score between the students in science and non-science focused programs $(t=0.826, p<0.41)$, or between the $2016(11.7 / 18)$ and 2017 cohorts $(11.3 / 18), t=1.6, p<0.12$. Results from both years showed a similar pattern of correct and incorrect answers (Figure 1).

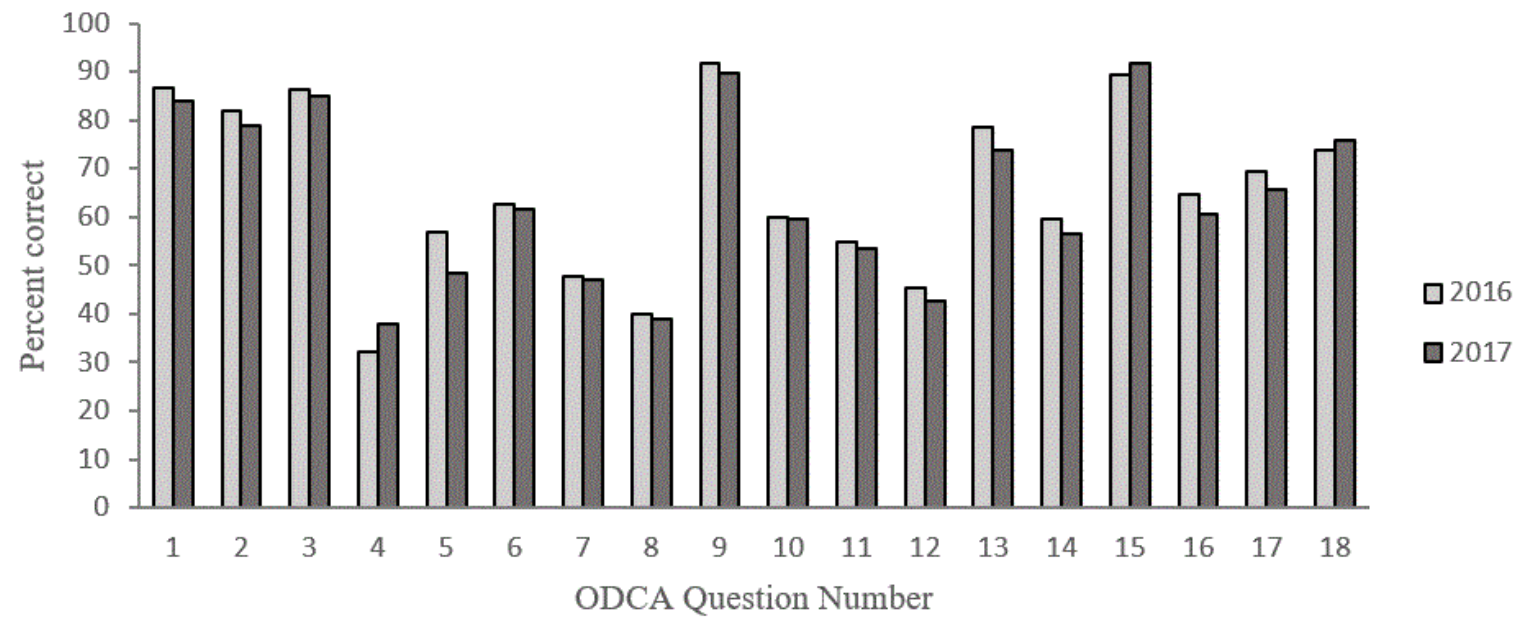

Figure 1: The percentage of students answering each question correctly in 2016 and 2017.

Questions in the conceptual assessment were divided into three categories based on topic: semipermeable membranes; molecular movement; and water as a solvent.

\section{Semipermeable membranes (question sets $1 / 2,7 / 8,11 / 12$ and 13/14)}

Questions 1 and 2 had the highest number of correct responses of all question sets. More than $70 \%$ of participants correctly answered both questions 1 and 2, identifying and defining semipermeable membranes (Table 2A). However, students scored much lower on the questions that applied this concept. Question 7 asked about the movement of molecules across a semipermeable membrane. Only $47 \%$ of students were able to correctly identify which of the water levels would be higher after a period of time, and only $30 \%$ of these were also able to identify the correct answer for the correct reason. Two distractors were selected by about $25 \%$ 
of students; the first 'water will move from high to low solute concentration' and the second distractor represents the misconception that water has to be level on both sides of the membrane. Question 11 asked about the movement of water and dye molecules through a semipermeable membrane. About $54 \%$ of students were able to correctly identify the outcome 'the level of the liquids on both sides will remain the same', but only $36 \%$ of students selected the correct response for the correct reason, that is 'water and dye can both pass through the membrane'. Distractors about the rate of diffusion of different molecules and the volume of dye molecules were also popular choices. Question set 13/14 asked about osmosis and animal cells, and correct answers required knowledge of both the movement of molecules and semipermeable membranes. Only 54\% of students correctly identified that red blood cells will swell and burst when placed in water (question 13) due to water moving to where there was a lower water concentration (question 14). The most popular distractor was the explanation: 'water molecules move from higher concentration of dissolved particles to lower concentration of dissolved particles'. Almost one quarter of students incorrectly selected that the size of the molecules is affected by temperature.

Table 2A. Questions and responses about semi-permeable membranes on the ODCA* completed by Cell Biology students (combined 2016 and 2017).

\begin{tabular}{|l|c|c|}
\hline & $\begin{array}{c}\text { Combined } \\
\%\end{array}$ & $\begin{array}{c}\text { Correct for } \\
\text { correct } \\
\text { reason } \\
\%\end{array}$ \\
\hline 1. All cell membranes are & 85.1 & \\
\hline a. semipermeable. & 14.7 & \\
\hline b. permeable. & & \\
\hline 2. The reason for my answer is because cell membranes & 7.5 & \\
\hline a. allow free movement of materials into or out of the cell. & 7.9 & \\
\hline $\begin{array}{l}\text { b. allow some substances to enter the cell, while they prevent } \\
\text { all substances from leaving. }\end{array}$ & 7.2 & \\
\hline c. allow only beneficial materials to enter the cell. & 80.4 & \\
\hline d. allow some substances to pass through, but not others. & & \\
\hline & & \\
\hline $\begin{array}{l}\text { 7. In Figure 1, two columns of water are separated by a } \\
\text { semipermeable membrane through which only water } \\
\text { molecules can pass. Side 1 contains brown dye and water; } \\
\text { Side 2 contains pure water. After two hours, the water level } \\
\text { in Side 1 will be ... }\end{array}$ & & \\
\hline a. higher than in Side 2. & 47.3 & \\
\hline b. lower than in Side 2. & 27.1 & \\
\hline c. the same height as in Side 2. & 25.6 & \\
\hline 8. The reason for my answer is because & & \\
\hline a. water will move from high to low solute concentration. & 24.7 & \\
\hline b. water flows freely and maintains equal levels on both sides. & 23.1 & \\
\hline c. the concentration of water molecules is less on Side 1. & 39.4 & \\
\hline d. water moves from low to high water concentration. & 12.8 & \\
\hline & & \\
\hline
\end{tabular}




\begin{tabular}{|c|c|c|}
\hline $\begin{array}{l}\text { 11. A water-based solution is placed on the left side of a } \\
\text { container that is divided by a semipermeable membrane } \\
\text { (Figure 3). Pure water is on the right. As time passes, the } \\
\text { right side gradually becomes blue, while the blue colour on } \\
\text { the left side becomes lighter. This suggests that }\end{array}$ & & \\
\hline a. the level of the liquids on both sides will remain the same. & 54.1 & \\
\hline $\begin{array}{l}\text { b. the level of the liquid will decrease on Side } 1 \text { and increase } \\
\text { on Side } 2 .\end{array}$ & 34.8 & \\
\hline $\begin{array}{l}\text { c. the level of the liquid will increase on Side } 1 \text { and decrease } \\
\text { on Side } 2 .\end{array}$ & 11.0 & \\
\hline 12. The reason for my answers is that & & \\
\hline a. water and dye can both pass through the membrane. & 44.0 & \\
\hline $\begin{array}{l}\text { b. the dye can pass through the membrane but moves more } \\
\text { slowly than water. }\end{array}$ & 26.9 & \\
\hline c. the dye moves into Side 2 and raises the level of the liquid. & 21.6 & \\
\hline $\begin{array}{l}\text { d. atmospheric pressure will always produce equal water } \\
\text { levels. }\end{array}$ & 7.5 & \\
\hline & & 36.1 \\
\hline $\begin{array}{l}\text { 13. When a living human blood cell is placed in pure fresh } \\
\text { water, the cell will }\end{array}$ & & \\
\hline a. shrivel up. & 12.0 & \\
\hline b. swell and burst. & 76.2 & \\
\hline c. remain the same. & 11.7 & \\
\hline 14. The reason for my answer is because & & \\
\hline $\begin{array}{l}\text { a. water molecules move from higher concentration of } \\
\text { dissolved particles to lower concentration of dissolved } \\
\text { particles. }\end{array}$ & 19.0 & \\
\hline b. a cell has homeostasis and will maintain itself. & 10.9 & \\
\hline c. the cell loses stability outside the human body. & 12.0 & \\
\hline $\begin{array}{l}\text { d. water molecules move from higher concentration of water to } \\
\text { lower concentration of water. }\end{array}$ & 58.1 & \\
\hline & & 53.9 \\
\hline
\end{tabular}

*ODCA modified from Fisher et al., (2011); images are not reproduced here

\section{Movement of molecules (question sets 3/4, 5/6, 9/10, 15/16)}

Most students (86\%) were able to identify that during diffusion, particles will generally move from high concentration to low concentrations (question 3; Table 2B). However, only around $35 \%$ of students were able to pick the correct reason for the direction of particle movement, that is, 'the random motion of particles suspended in a fluid results in their uniform distribution'. Two distractors were selected by about $30 \%$ of students, one anthropomorphising the particles and the other representing the misconception that molecules will move for a reason and will then stop. Question set 5/6 required students to identify that salt molecules will become evenly distributed within a solution due to the process of diffusion. Approximately half of the students correctly identified that an even distribution of the molecules will result, and about $62 \%$ identified that particles will move from an area of high to an area of low concentration (i.e. the definition of diffusion). Over $90 \%$ of students correctly identified that at a higher temperature, diffusion will occur more rapidly (question 9), however only $60 \%$ students selected the correct reason 'that the dye molecules move faster' (question 10). 
Table 2B. Questions and responses about the movement of molecules on the ODCA* completed by Cell Biology students (combined 2016 and 2017).

\begin{tabular}{|c|c|c|}
\hline & $\begin{array}{l}\text { Combined } \\
\%\end{array}$ & $\begin{array}{c}\text { Correct for } \\
\text { correct } \\
\text { reason } \\
\%\end{array}$ \\
\hline \multicolumn{3}{|l|}{$\begin{array}{l}\text { 3. During the process of diffusion, particles will generally } \\
\text { move from }\end{array}$} \\
\hline a. high to low concentration. & 85.5 & \\
\hline b. low to high concentration. & 14.1 & \\
\hline \multicolumn{3}{|l|}{ 4. The reason for my answer is because } \\
\hline a. crowded particles want to move to an area with more room. & 30.0 & \\
\hline $\begin{array}{l}\text { b. the random motion of particles suspended in a fluid results } \\
\text { in their uniform distribution. }\end{array}$ & 35.2 & \\
\hline $\begin{array}{l}\text { c. the particles tend to keep moving until they are uniformly } \\
\text { distributed and then they stop moving. }\end{array}$ & 30.9 & \\
\hline \multirow[t]{2}{*}{ d. there is a greater chance of the particles repelling each other. } & 3.9 & \\
\hline & & 30.7 \\
\hline \multicolumn{3}{|l|}{$\begin{array}{l}\text { 5. If a small amount of salt ( } 1 \mathrm{tsp} \text { ) is added to a large } \\
\text { container of water ( } 4 \text { litres) and allowed to set for several } \\
\text { days without stirring, the salt molecules will }\end{array}$} \\
\hline a. be more concentrated on the bottom of the water. & 47.3 & \\
\hline b. be evenly distributed throughout the container. & 52.5 & \\
\hline \multicolumn{3}{|l|}{ 6. The reason for my answer is because } \\
\hline a. salt is heavier than water and will sink. & 15.8 & \\
\hline b. salt dissolves poorly or not at all in water. & 9.3 & \\
\hline c. there will be more time for settling. & 12.8 & \\
\hline \multirow[t]{2}{*}{$\begin{array}{l}\text { d. there is movement of particles from a high to low } \\
\text { concentration. }\end{array}$} & 62.1 & \\
\hline & & 48.8 \\
\hline \multicolumn{3}{|l|}{$\begin{array}{l}\text { 9. Suppose there are two large beakers with equal amounts of } \\
\text { clear water at two different temperatures (see Figure } 2 \text { ). } \\
\text { Next, a drop of green dye is added to each beaker of water. } \\
\text { Eventually the water turns light green. In which beaker does } \\
\text { the water become evenly coloured light green first? }\end{array}$} \\
\hline a. Beaker 1 & 9.0 & \\
\hline b. Beaker 2 & 90.6 & \\
\hline \multicolumn{3}{|l|}{ 10. The reason for my answer is because } \\
\hline a. the dye breaks down more quickly. & 13.0 & \\
\hline b. moving slower makes it easier for the molecules to move. & 2.9 & \\
\hline c. the dye molecules move faster. & 59.7 & \\
\hline \multirow[t]{2}{*}{ d. temperature changes the size of the molecules. } & 24.4 & \\
\hline & & 56.1 \\
\hline \multicolumn{3}{|l|}{$\begin{array}{l}\text { 15. Suppose you add a drop of blue dye to a container of } \\
\text { clear water and after several hours the fluid is evenly } \\
\text { coloured light blue. At this time, the molecules of dye }\end{array}$} \\
\hline a. have stopped moving. & 8.9 & \\
\hline
\end{tabular}




\begin{tabular}{|l|c|c|}
\hline b. continue to move around randomly. & 90.7 & \\
\hline 16. The reason for my answer is because & 7.6 & \\
\hline $\begin{array}{l}\text { a. molecules move until they are evenly distributed, and then } \\
\text { they stop. }\end{array}$ & 12.6 & 62.8 \\
\hline $\begin{array}{l}\text { b. if the dye molecules stopped, they would settle to the bottom } \\
\text { of the container. }\end{array}$ & 17.1 & \\
\hline $\begin{array}{l}\text { c. when molecules are evenly distributed, they still continue to } \\
\text { move. }\end{array}$ & & 59.1 \\
\hline $\begin{array}{l}\text { d. this is a liquid system. If it were a solid the molecules } \\
\text { would stop moving. }\end{array}$ & & \\
\hline
\end{tabular}

*ODCA modified from Fisher et al., (2011); images are not reproduced here

\section{Water as a solvent (question set 17/18)}

Questions 17 asked about two solutions containing different concentrations of salt. Approximately $58 \%$ of students correctly selected that more water would be in the beaker that contained fewer dissolved particles (lower salt concentration; Table 2C). However, $17 \%$ of students disregarded the contribution that the dye particles made to the volume of the solution by selecting 'the liquids are the same heights in both beakers'.

Table 2C. Questions and responses about water as a solvent on the ODCA* completed by Cell Biology students (combined 2016 and 2017).

\begin{tabular}{|l|c|c|}
\hline & $\begin{array}{c}\text { Combined } \\
\%\end{array}$ & $\begin{array}{c}\text { Correct for } \\
\text { correct } \\
\text { reason } \\
\%\end{array}$ \\
\hline $\begin{array}{l}\text { 17. Figure 4 depicts a case where two water solutions have } \\
\text { just been introduced into two identical beakers. The volume } \\
\text { of the solution in each beaker is the same. At this point, } \\
\text { Beaker 1 contains }\end{array}$ & & \\
\hline a. more water than Beaker 2. & 67.4 & \\
\hline b. less water than Beaker 2. & 15.1 & \\
\hline c. the same amount of water as Beaker 2. & 17.2 & \\
\hline 18. The reason for my answer is because & 17.1 & \\
\hline a. the liquids are the same heights in both beakers. & 7.7 & \\
\hline b. water in Beaker 1 contains more dissolved particles. & 74.7 & \\
\hline c. water in Beaker 1 contains fewer dissolved particles. & & 57.9 \\
\hline \multicolumn{2}{|l|}{} \\
\hline
\end{tabular}

*ODCA modified from Fisher et al., (2011); images are not reproduced here

\section{Discussion}

First-year Cell Biology students at a regional university in Australia completed the ODCA, a conceptual assessment on osmosis and diffusion. The results of this assessment were consistent across two consecutive years, across 8 key programs, and identified several areas of inadequate knowledge and misconceptions. 
Diagnostic tests, such as the ODCA, have successfully been used by both educators and researchers to identify areas of poor student knowledge, to highlight topics where students are mis-informed, and to evaluate the effects of external factors on student knowledge and misknowledge. Cell Biology students in the present study achieved an overall mean score of $11.5 / 18(S D=3.3)$ on the ODCA, which represents the overall student conceptual understanding of osmosis and diffusion (Griffard \& Wandersee, 2001). Although the overall score from students in previous research was not available, the score in the current study was considerably lower than the 16.5/18 achieved by high school teachers and college instructors (Fisher et al., 2011). The Cell Biology students generally performed better on the tier one questions (what?) compared to the tier two questions (why?), consistent with previous ODCA results of university students (Fisher et al., 2011) and with other two-tiered conceptual assessments (Kiliç \& Sağlam, 2009; Othman, Treagust, \& Chandrasegaran, 2008). This result was also consistent with studies of university and high school students using the similarly structured DODT conceptual assessment (Odom \& Barrow, 1995; Sun, Looi, \& Xie, 2017). Fisher et al. (2011) proposed that students perform better on the tier one questions because they can predict the outcome of these questions but do not understand the processes involved or the underlying mechanisms that are assessed in the tier two questions. Alternatively, this pattern of correct-incorrect responses could be partly explained by there being fewer distractor options in the tier one questions.

In the present study, of the nine pairs of questions, those that involved predicting the movement of water and/or dye molecules across a semipermeable membrane (question sets 7/8, 11/12, 13/14) had among the lowest combined number of correct responses. However, correct responses to question set $1 / 2$, which required students to know the definition of semipermeable membranes and the fact that cell membranes are semipermeable, received the highest number of correct responses. These results suggest that students know or are familiar with the definition of semipermeability but cannot then apply this information to other situations. In explaining why molecules move from an area of high concentration to an area of low concentration during the process of diffusion, almost one third of the students in the present study erroneously chose the option 'crowded particles want to move to an area with more room'. Several previous studies have also reported students using similar anthropomorphic constructs to describe biological processes, for example, believing that molecules move or behave in a certain way because they 'want to' (Fisher et al., 2011; Friedler, Amir, \& Tamir, 1987; Odom, 1995; Odom \& Barrow, 1995; Sanger et al., 2001; Shen, Liu, \& Sung, 2014; Tekkaya, 2003; Zuckerman, 1994).

Misconceptions about the concepts of osmosis and/or diffusion that are held by both high school and university biology students have been identified by numerous researchers and teachers (Artun \& Coştu, 2013; Marek, Cowan, \& Cavallo, 1994; Odom, 1995; Odom \& Barrow, 1993; Odom \& Barrow, 1995; Odom \& Barrow, 2007; Westbrook \& Marek, 1991; Zuckerman, 1994). Results from the present study identified four misconceptions in student understanding of osmosis and diffusion.

\section{Misconception 1. Water will level out (question sets $7 / 8$ and 17/18)}

Approximately one quarter of students responded that the water levels should be equal in question 7 and that 'water flows freely and maintains equal levels', suggesting a misunderstanding of the general properties of water and of its movement through semipermeable membranes. Water levelling out at the macro scale makes intuitive sense based on life experience with water filling containers and becoming 'level'. It is clear from these 
responses that a deeper understanding of the chemical and physical nature of water at the molecular scale, and of the pressures and forces that determine its movement across semipermeable membranes, are required to correctly answer the second part of this question set. It is possible that greater hands-on exposure to non-intuitive behaviour of liquids in the macro world, like wicking and siphoning, would expand the students' reasoning beyond this basic intuition.

\section{Misconception 2. Dissolved substances will eventually settle out (question set 5/6)}

Nearly half of all students indicated that salt would settle out of solution if left for several days, with a variety of explanations chosen. It is possible that without having studied the content, students are relying on their intuition to infer that any dissolved particles will settle out of water with time. It is also possible that students who selected the incorrect answers to this question set may be confusing a suspension with a solution; assuming salt will behave like sand in water if there is no stirring or agitation. Nearly $10 \%$ of the students appear to have very little exposure to basic kitchen science experiments, believing that 'salt dissolves poorly in water'. Odom and Barrow (1995) presented a similar question to first year university biology students, with 'salt' in the ODCA question replaced by 'sugar'. Many students chose the incorrect option 'sugar is heavier than water and will sink'. Odom and Barrow (1995) suggested the reason for this selection was that students were integrating gravity concepts into solution chemistry.

\section{Misconception 3. Not understanding Brownian motion; believing molecules/ions eventually settle out of solution (question sets $3 / 4$ and 15/16)}

Question sets 3/4 and 15/16 ask about the process of diffusion, with both offering the incorrect option that molecules/particles will stop moving once they are evenly distributed. Question set $3 / 4$ is about the direction of particle movement during diffusion (high concentration to low concentration) and approximately 30\% of students selected the incorrect response that 'the particles tend to keep moving until they are uniformly distributed and then they stop moving'. Fisher et al. (2011) concluded that many students believe that molecules only move around if there is a reason to do so, that is, if there is a concentration gradient that needs to be changed or fixed. Question set 15/16 is about the diffusion of dye molecules in water, and only $7.6 \%$ of students incorrectly answered that the molecules would stop moving when evenly distributed. Approximately $91 \%$ of students selected the correct response, that once the fluid becomes evenly coloured the molecules of dye 'will continue to move around randomly' and 59\% of students were able to identify the correct response for the correct reason.

\section{Misconception 4. All things expand and contract with temperature (question set 9/10)}

Question 10 describes two beakers of water at different temperatures to which a drop of dye is added. Approximately $90 \%$ of students selected the correct option that the beaker with the higher temperature water will become evenly coloured more quickly than the cooler beaker. However, when explaining why this occurs, almost one quarter of students incorrectly selected 'temperature changes the size of the molecules'. The idea that solids, liquids and gases expand with increasing temperature and contract with decreasing temperature applies to most substances. However, these laws are not relevant to the size of the particles that are being heated or cooled (Brown, Lemay, Bursten, \& Murphy, 2009). It seems that many students do not understand that heat increases the kinetic energy of molecules and how this relates to movement and expansion. Instead, many students relate an increase in heat to an increase in the size of atoms and molecules. 
Of the numerous misconceptions about osmosis and diffusion that have been documented, many can be grouped into problems understanding: energy (Brownian motion, kinetic energy and temperature); concentrations and concentration gradients; and properties of the cell membrane (semipermeability). There is considerable overlap between previously reported misconceptions and those identified in the present study, which suggests that the common ways in which osmosis and diffusion are taught and/or learned may be a factor in the development of these misconceptions. Kramer and Myers (2012) suggested that the use of analogies and non-scientific language by teachers to explain these concepts may be partly to blame for their popularity. Badenhorst et al. (2016) proposed that misconceptions can arise as the result of students relying on rote learning rather than by utilising strategies that promote deep learning. The misconceptions identified in the present study indicate that Cell Biology students have a superficial and often inaccurate knowledge of osmosis and diffusion. Another possibility is that students were familiar with the words/word combinations used but had no real understanding of the concepts. In other words, students may have selected answers based on word familiarity (see below) rather than based on content knowledge. Several researchers have suggested that misconceptions may arise due to the use of overcomplicated or oversimplified images in attempts to assist students to understand abstract concepts (Schönborn \& Anderson, 2006; Schönborn, Anderson, \& Grayson, 2002; Wheeler \& Hill, 1990). Numerous studies have reported that many students do not have the visual-spatial skills necessary to visualise complex microscopic structures and molecular interactions, and it is therefore difficult for them to achieve a conceptual understanding based on abstract teaching (Cottam, 1999; Dev et al., 2002; Garg, Norman, \& Sperotable, 2001; Miller, 2000; Silén, Wirell, Kvist, Nylander, \& Smedby, 2008). Regardless of the source, it is essential that misconceptions and lack of understanding be corrected to facilitate the learning of basic concepts in biological sciences and how they are applied to more complex ideas.

Gooding and Metz (2011) described misconceptions as being resistant to rectification. In order to remediate, misconceptions must be identified and learners must be willing/encouraged to confront the discrepancy in their beliefs (Yong \& Ch'ng, 2017). This process can be facilitated by the provision of activities and learning aids that are learner-centred (Bonk \& Cunningham, 1998). Attempts to assist students to master the concepts of osmosis and diffusion are greatly varied. One approach employed by Tekkaya (2003) used conceptual change instructional strategies to alert students to the misconceptions they hold and then to inform students of the scientific explanations that disprove their beliefs. Haddad and Baldo (2010) described a coin tossing exercise designed to assist students to understand the random processes that are central to the process of diffusion. Several studies have reported the use of multimedia simulations to assist students to master concepts, prevent the development of misconceptions, or correct existing misconceptions. For example, animations have been created to simulate: cell division (Elangovan, 2017), photosynthesis (Mikropoulos, Katsikis, Nikolou, \& Tsakalis, 2003), diffusion and osmosis (Meir, Perry, Stal, Maruca, \& Klopfer, 2005; Sanger et al., 2001; Sung, Shen, Jiang, \& Chen, 2017), and protein interactions and dynamics in ligand-receptor complexes (Jenkinson, McGill, \& Liu, 2012). These studies have had mixed success. For example, Meir et al. (2005) introduced inquiry-based simulated laboratory experiments about osmosis and diffusion in addition to providing lectures and wet laboratory experiments. These researchers concluded that this combination dispelled some, but not all of the misconceptions held by the students.

The conceptual assessment used in the present study, the ODCA, was chosen as it had been validated, refined over several iterations, and then tested with a large number of post-high 
school students (Fisher et al., 2011). However, in addition to what was described earlier in Misconception 3, there are two areas in which the structure of a question or possible response options may have influenced students' choice of answers. Firstly, there are several answers within the assessment that describe a 'high' to 'low' change (answers 3a, 6d, 8a, 14a and 14d). When these options were distractors (answers $8 \mathrm{a}, 14 \mathrm{a}$ ), they were the most frequently chosen. It is possible that students selected these responses based on superficial word matching rather than on careful thought about the question, the correctness of each answer option, and a choice based on knowledge and a degree of certainty that the answer is correct. Odom and Barrow (1995) postulated that students chose an item response in the DODT due to word recognition, recognising the key prefix 'iso'. Secondly, students performed poorly on questions 11 and 12, with only $36.1 \%$ of students correctly answering both questions. Similarly, students in the study by Fisher et al. (2011) performed poorly on this question set (34.1\% biology non-majors and $44.6 \%$ biology majors). It is possible that this question is confusing and/or misleading, because in the context of the question (question 11), the membrane is identified as being semipermeable; however, it is permeable to both the dye and water molecules discussed in the question. The poor performance of students in both studies on this question set may have more to do with the wording of the questions, rather than being an indication of students' poor conceptual understanding.

To understand the concepts of osmosis and diffusion, knowledge of kinetic energy, Brownian motion, concentrations and concentration gradients as well as properties of the cell membrane (semipermeability) are essential. A detailed survey of the students' science background was not in the scope of our study. However, it is recommended that future studies investigate the students' prior learning in chemistry to explore relationships between knowledge of the above topics and the frequency/type of misconceptions about osmosis and diffusion. A diagnostic assessment in multiple choice format was chosen to facilitate the large sample size of the Cell Biology cohort. Future investigations could explore these misconceptions using short answer questions or interviews to gain a more detailed understanding of student misconceptions and the origins of these beliefs. This information will facilitate the development of questionnaires that are more easily understood, and assist instructors in providing ways for students to confront and rectify their incorrect understanding of osmosis and diffusion.

\section{Conclusions}

This study describes osmosis and diffusion misconceptions held by first year biology students at a regional Australian university. Student knowledge of osmosis and diffusion, as evaluated by the ODCA, was found to be similar to that of biology students at a Californian university in a study by Fisher et al. (2011). Common misconceptions held by the Australian cohorts included: a belief that dissolved substances will eventually settle out of solutions; that water will reach equal levels; that molecules change size with temperature changes; and that molecules will stop moving once evenly distributed. These misconceptions must be identified early in the first year course and be addressed with more detailed visualisations of cell processes. Frequent re-testing should be conducted to establish whether or not student understanding was achieved. It would also be of interest to discover if these basic misconceptions persist as students move into more advanced science courses.

\section{Acknowledgments}

This project was funded by a University of the Sunshine Coast Commissioned Learning and Teaching Grant. 


\section{References}

Anderson, C. W., Sheldon, T. H., \& Dubay, J. (1990). The effects of instruction on college nonmajors' conceptions of respiration and photosynthesis. Journal of Research in Science Teaching, 27(8), 761-776.

Artun, H., \& Coştu, B. (2013). Effect of the 5E model on prospective teachers' conceptual understanding of diffusion and osmosis: a mixed method approach. Journal of Science Education and Technology, 22(1), 110. doi:10.1007/s10956-012-9371-2

Bada, D., \& Olusegun, S. (2015). Constructivism learning theory: a paradigm for teaching and learning. IOSR Journal of Research and Method in Education, 6(1), 66-70. doi:10.9790/7388-05616670

Badenhorst, E., Hartman, N., \& Mamede, S. (2016). How biomedical misconceptions may arise and affect medical students' learning: a review of theoretical perspectives and empirical evidence. Health Professions Education, 2(1), 10-17. doi:10.1016/j.hpe.2016.01.005

Bekkink, M. O., Rogier Donders, A. R. T., Kooloos, J. A., de Wall, R. M. W., \& Ruiter, D. J. (2016). Uncovering students' misconceptsions by assessment of their written questions. BMC Medical Education, 16(1), 1-7. doi:10.1186/s12909-016-0739-5

Blackley, S., \& Howell, J. (2015). A STEM narrative: 15 years in the making. Australian Journal of Teacher Education, 40(7), Article 8. Retrieved from https://ro.ecu.edu.au/ajte/vol40/iss47/48/ doi:10.14221/ajte.2015v40n7.8

Bone, E. K., \& Reid, R. J. (2011). Prior learning in biology at high school does not predict performance in the first year at university. Higher Education Research and Development, 30(6), 709-724. doi:10.1080/07294360.2010.539599

Bonk, C. J., \& Cunningham, D. J. (1998). Searching for learner-centered, constructivist, and sociocultural components of collaborative educational learning tools. In C. J. Bonk \& K. S. King (Eds.), Electronic collaborators: learner-centered technologies for literacy, apprenticeship, and discourse (pp. 25-50). Mahwah, NJ: Lawrence Erlbaum Associates, Inc.

Bowling, B. V., Acra, E. E., Wang, L., Myers, M. F., Dean, G. E., Markle, G. C., \& Heuether, C. A. (2008). Development and evaluation of a genetics literacy assessment instrument for undergraduates. Genetics, 178(1), 15-22. doi:10.1534/genetics.107.079533

Brown, T. L., Lemay, H. E., Bursten, B. E., \& Murphy, C. J. (2009). Chemistry. The central science. (11th ed.). Upper Saddle River, N.J.: Pearson Education Inc.

Burke da Silva, K., \& Hunter, N. (2009). The use of pre-lectures in a university biology course - eliminating the need for prerequisites. Biosciences Education, 14(1), 1-7. doi:10.3108/beej.14.2

Chubb, I. (2011). Opening address to the National Forum on Education in the Biomedical Sciences. Paper presented at the National Forum on Education in the Biomedical Sciences., Canberra. Retrieved from https://www.chiefscientist.gov.au/2011/12/national-forum-on-education-in-the-biomedical-sciences/

Chubb, I. (2012). Mathematics, engineering \& science in the national interest: Office of the Chief Scientist, Canberra. Retrieved from https://www.chiefscientist.gov.au/wp-content/uploads/Office-of-the-ChiefScientist-MES-Report-8-May-2012.pdf.

Çimer, A. (2012). What makes biology learning difficult and effective: students' views. Educational Research and Reviews, 7(3), 61-71.

Collier, P. J., \& Morgan, D. L. (2008). Is that paper really due today? Differences in first-generation and traditional college students' understanding of faculty expectations. Higher Education, 55(4), 525-446. doi:10.1007/s10734-007-9065-5

Cottam, W. W. (1999). Adequacy of medical school gross anatomy education as perceived by certain postgraduate residency programs and anatomy course directors. Clinical Anatomy, 12(1), 55-65. doi:10.1002/(sici)1098-2353(1999)12:1<55::aid-ca8>3.0.co;2-o

Dev, P., Montgomery, K., Senger, S., Heinrichs, W. L., Srivastava, S., \& Waldron, K. (2002). Simulated medical learning environments on the Internet. Journal of the American Medical Informatics Association, 9(5), 437-447. doi:10.1197/jamia.m1089

Elangovan, T. (2017). Comparison between realistic and non-realistic simulations in reducing secondary school students' misconceptsion on mitosis and meiosis processes. In M. Karpudewan, A. N. M. Zain, \& A. L. Chandrasegaran (Eds.), Overcoming students' misconceptions in science (pp. 307-322). Singapore: Nature.

Ferdig, R., Blank, J., Kratcoski, A., \& Clements, R. (2015). Using stereoscopy to teach complex biological concepts. Advances in Physiology Education, 39(3), 205-208. doi:10.1152/advan.00034.2014

Fisher, K. M., Williams, K. S., \& Lineback, J. E. (2011). Osmosis and diffusion conceptual assessment. CBELife Sciences Education, 10(4), 418-429. doi:10.1187/cbe.11-04-0038

Friedler, Y., Amir, R., \& Tamir, P. (1987). High school students' difficulties in understanding osmosis. International Journal of Science Education, 9(5), 541-551. doi:10.1080/0950069870090504

Garg, A. X., Norman, G., \& Sperotable, L. (2001). How medical students learn spatial anatomy. The Lancet, 357(9253), 363-364. doi:10.1016/s0140-6736(00)03649-7 
Gooding, J., \& Metz, B. (2011). From misconceptions to conceptual change: tips for identifying and overcoming students' misconceptions. The Science Teacher, 2(4), 34-37.

Graham, C. M., Addy, H. D., Huddleston, W. R., \& Stallard, J. (2011). Evaluating student learning in large introductory biology courses; predictors of student success and lessons for course redesign. Paper presented at the The Western Conference on Science Education, The University of Western Ontario, Canada.

Griffard, P. B., \& Wandersee, J. H. (2001). The two-tier instrument on photosynthesis: what does it diagnose? International Journal of Science Education, 23(10), 1039-1052. doi:10.1080/09500690110038549

Haddad, H., \& Baldo, M. V. C. (2010). Teaching diffusion with a coin. Advances in Physiology Education, 34(3), 156-157. doi:10.1152/advan.00009.2010

Haslam, F., \& Treagust, D. F. (1987). Diagnosing secondary students' misconceptions of photosynthesis and respiration in plants using a two tier multiple choice instrument. Journal of Biological Education, 21(3), 203-211.

Jenkinson, J., McGill, G., \& Liu, D. W. C. (2012). Visualizing protein interactions and dynamics: evolving a visual language for molecular animation. CBE_Life Sciences Education, 11(1), 103-110. doi:10.1187/cbe.11-08-0071

Johnson, A. M., \& Lawson, E. A. (1998). What are the relative effects of reasoning ability and prior knowledge on biology achievement in expository and inquiry classes? Journal of Research in Science Teaching, 35(1), 89-103. doi:10.1002/(sici)1098-2736(199801)35:1<89::aid-tea6>3.0.co;2-j

Johnson, C. C. (2012). Implementation of STEM education policy: challenges, progress, and lessons learned. School Science and Mathematics, 112(1), 45-55. doi:10.1111/j.1949-8594.2011.00110.x

Kennedy, J., Lyons, T., \& Quinn, F. (2014). The continuing decline of sceince and mathematics enrolments in Australian high schools. Teaching Science, 60(2), 34-46.

Kift, S. (2015). A decade of transition pedagogy: a quantum leap in conceptualising the first year experience. HERDSA Review of Higher Education, 2, 51-86.

Kiliç, K., \& Sağlam, N. (2009). Development of a two-tier diagnostic test concerning genetics concepts: the study of validity and reliability. Procedia Social and Behavioural Sciences, 1(1), 2685-2686. doi:10.1016/j.sbspro.2009.01.474

King, C., \& James, R. (2013). Creating a demand-driven system. In S. Marginson (Ed.), Tertiary Education Policy in Australia (pp. 11-19). Melbourne, VIC: Centre for the Study of Higher Education, University of Melbourne.

Kramer, E. M., \& Myers, D. R. (2012). Five popular misconceptions about osmosis. American Journal of Physics, 80(8), 694-699. doi:10.1119/1.4722325

Lazarowitz, R., \& Lieb, C. (2006). Formative assessment pre-test to identify college students' prior knowledge misconceptions and learning difficulties in biology. International Journal of Innovation in Science and Mathematics Education (formerly CAL-laborate International), 4(4), 741-762. doi:10.1007/s10763-0059024-5

Marek, E., Cowan, C., \& Cavallo, A. (1994). Students' misconceptions about diffusion: how can they be eliminated? The American Biology Teacher, 56(2), 74-77. doi:10.2307/4449757

Marginson, S., Tytler, R., Freeman, B., \& Roberts, K. (2013). STEM: country comparisons: international comparisons of science, technology, engineering and mathematics (STEM) education. Final report. Melbourne, VIC: Australian Council of Learned Academies.

McCoy, E. D., \& Pierce, S. K. (2004). The function of course prerequisites in biology. Retrieved from American Instute of Biological Sciences: http://www.actionbioscience.org/education/mccoy_pierce.html?pr

Meir, E., Perry, J., Stal, D., Maruca, S., \& Klopfer, E. (2005). How effective are simulated molecular-level experiements for teaching diffusion and osmosis? Cell Biology Education, 4(3), 235-248. doi:10.1187/cbe.04-09-0049

Michael, J., William, C., McFarland, J., Modell, H., \& Wright, A. (2017). The core concepts of physiology. New York, NY: Springer.

Mikropoulos, T. A., Katsikis, A., Nikolou, e., \& Tsakalis, P. (2003). Virtual environments in biology teaching. Journal of Biological Education, 37(4), 176-181. doi:10.1080/00219266.2003.9655879

Miller, R. (2000). Approaches to learning spatial relationships in gross anatomy: perspective from wider principles of learning. Clinical Anatomy, 13(6), 439-443. doi:10.1002/1098-2353(2000)13:6<439::aidca8>3.0.co;2-x

Odom, A. L. (1995). Secondary and college biology students' misconceptions about diffusion and osmosis. The American Biology Teacher, 57(7), 409-415. doi:10.2307/4450030

Odom, A. L., \& Barrow, L. H. (1993). Freshman biology majors' misconceptions about diffusion and osmosis. Paper presented at the Annual Meeting of the National Association for Research in Science Teaching, Atlanta, GA. Retrieved from http://files.eric.ed.gov/fulltext/ED362399.pdf 
Odom, A. L., \& Barrow, L. H. (1995). Development and application of a two-tier diagnostic test measuring college biology students' understanding of diffusion and osmosis after a course of instruction. Journal of Research in Science Teaching, 32(1), 45-61. doi:10.1002/tea.3660320106

Odom, A. L., \& Barrow, L. H. (2007). High school biology students' knowledge and certainty about diffusion and osmosis concepts. School Science and Mathematics, 107(3), 94-101. doi:10.1111/j.19498594.2007.tb17775.x

Othman, J. B., Treagust, D. F., \& Chandrasegaran, A. L. (2008). An investigation into the relationship between students' ideas about particles and their understanding of chemical bonding using a two-tier diagnostic instrument. International Journal of Science Education, 30(11), 1531-1550. doi:10.1080/09500690701459897

Phillips, D. C. (1995). The good, the bad, and the ugly: the many faces of constructivism. Educational Researcher, 24(7), 5-12. doi:10.2307/1177059

Rayner, G. (2014). A review of the value of prior learning in first year biology. International Journal of Innovation in Science and Mathematics Education, 22(2), 55-64.

Sadler, P. M., \& Tai, R. H. (2007). The two high-school pillars supporting college science. Science, 317(5837), 457-458. doi:10.1126/science. 1144214

Sanger, M. J., Brecheisen, D. M., \& Hynek, B. M. (2001). Can computer animations affect college biology students' conceptions about diffusion \& osmosis? The American Biology Teacher, 63(2), 104-109. doi:10.1662/0002-7685(2001)063[0104:CCAACB]2.0.CO;2

Schönborn, K. J., \& Anderson, T. R. (2006). The importance of visual literacy in the education of biochemists. Biochemistry and Molecular Biology Education, 34(2), 94-102. doi:10.1002/bmb.2006.49403402094

Schönborn, K. J., Anderson, T. R., \& Grayson, D. J. (2002). Student difficulties with the interpretation of a textbook diagram of immunoglobulin G (IgG). Biochemistry and Molecular Biology Education, 30(2), 9399. doi:10.1002/bmb.2002.494030020036

Shen, J., Liu, O. L., \& Sung, S. (2014). Designing interdisciplineary assessments in sciences for college students: an example on osmosis. International Journal of Science Education, 36(11), 1773-1793. doi:10.1080/09500693.2013.879224

Shimizu, D. (2015). Comparing learning gains: audio versus text-based instructor communication in a blended online learning environment (Doctor of Education Thesis). Northcentral University, Scottsdale, AZ.

Silén, C., Wirell, S., Kvist, J., Nylander, E., \& Smedby, Ö. (2008). Advanced 3D visualization in studentcentred medical education. Medical Teacher, 30(5), e115-e124. doi:10.1080/01421590801932228

Smith, J. P., diSessa, A. A., \& Roschelle, J. (1993). Misconceptions reconceived: a constructivist analysis of knowledge in transition. The Journal of the Learning Sciences, 3(2), 115-163. doi:10.1207/s15327809j1s0302_1

Smith, M. K., Wood, W. B., \& Knight, J. K. (2008). The genetics concept assessment: a new concept inventory for gauging student understanding of genetics. CBE Life Sciences Education, 7(4), 422-230. doi:10.1187/cbe.08-08-0045

Sturges, D., \& Maurier, T. (2013). Allied health students' perceptions of class difficulty: the case of undergraduate human anatomy and physiology classes. The Internet Journal of Allied Health Sciences and Practice, 11(14). Retrieved from https://nsuworks.nova.edu/ijahsp/vol11/iss14/19/

Sun, D., Looi, C.-K., \& Xie, W. (2017). Learning with collaborative inquiry: a science learning environemnt for secondary students. Technology, Pedagogy and Education, 26(3), 241-263. doi:10.1080/1475939X.2016.1205509

Sung, S. H.-H., Shen, J., Jiang, S., \& Chen, G. (2017). Comparing the effects of dynamic computer visualization on undergraduate students' understanding of osmosis with randomized posttest-only control group design. Research and Practice in Technology Enhanced Learning, 12(1). doi:10.1186/s41039-017-0067-3

Tan, D. K. C., \& Treagust, D. F. (1999). Evaluating students' understanding of chemical bonding. School Science Review, 81(294), 75-84.

Tekkaya, C. (2003). Remediating high school students' misconceptions concerning diffusion and osmosis through concept mapping and conceptual change text. Research in Science \& Technological Education, 21(1), 5-16. doi:10.1080/02635140308340

Thalluri, J. (2016). Bridging the gap to first year health science: Early engagement enhances student satisfaction and success. Student Success, 7(1), 37-48. doi: 10.5204/ssj.v7i1.305

Tibell, L. A. E., \& Rundgren, C.-J. (2010). Educational challenges of molecular life science: characteristics and implications for education and research. CBE Life Sciences Education, 9(1), 25-33. doi:10.1187/cbe.08-090055

Urry, L. A., Meyers, N., Cain, M. L., Wasserman, S. A., Minorsky, P. V., \& Reece, J. B. (2018). Campbell biology: Australian and New Zealand version. Melbourne, VIC: Pearson Australia.

Westbrook, S. L., \& Marek, E. A. (1991). A cross-age study of student understanding of the concept of diffusion. Journal of Research in Science Teaching, 28(8), 649-660. doi:10.1002/tea.3660280803 
Wheeler, A. E., \& Hill, D. (1990). Diagram-ease. The Science Teacher, 57(5), 58-63.

Yong, C. L., \& Ch'ng, Z. K. (2017). Utilizing concept cartoons to diagnose and remediate misconceptions related to photosynthesis among primary school students. In M. Karpudewan, A. L. Chandrasegaran, \& A. N. M. Zain (Eds.), Overcoming students' misconceptions in science (pp. 9-27). Singapore: Springer.

Zuckerman, J. (1994). Problem solver's conceptions about osmosis. The American Biology Teacher, 56(1), $22-$ 25. doi:10.2307/4449737 